\title{
Utilization of C-Cinnamal Calix[4] Resorcinarene as Adsorbent for Rhodamin B and Methanil Yellow
}

\author{
Sri Benti Etika ${ }^{1 *}$ Edi Nasra ${ }^{1}$ Abdul Hafids ${ }^{1}$ T K Sari ${ }^{1}$ \\ ${ }^{1}$ Dept. of Chemistry, Faculty of Mathematics and Science (FMIPA), Universitas Negeri Padang, Padang, Indonesia \\ ${ }^{*}$ Corresponding author. Email: sribentietika67@gmail.com
}

\begin{abstract}
The purpose of this study was to determine the optimum conditions i.e. $\mathrm{pH}$ and concentration of Rhodamin $\mathrm{B}$ and methanyl yellow using CCCR absorbent which is the result of synthesis by using the UV-VIS spectrophotometer. The method used was the adsorption method (Batch). Absorption of rhodamine B and methanyl yellow in solution by C-cinnamalCalix[4] Resorsinarena (CCCR) compound is carried out in a batch system at variations of $\mathrm{pH} 2,3,4,5,6,7$. At $\mathrm{pH} 4,5,6$ the amount of $\mathrm{H}+$ in the solution is more so that $\mathrm{H}+$ competition with rhodamin $\mathrm{B}$ is suspected to bind to the functional groups. Ion $\mathrm{H}+$ prevents rhodamine $\mathrm{B}$ from reaching the surface of the functional group, so the absorption at these $\mathrm{pH}$ is low. At $\mathrm{pH} 7$ occurs the competition of complex formation reaction between chelate compounds with hydroxide ions and this is the optimum $\mathrm{pH}$, while the optimum $\mathrm{pH}$ of methanyl yellow occurs at $\mathrm{pH} 3$. Variations in the concentrations of rhodamine $\mathrm{B}$ and methanyl yellow are carried out at their optimum $\mathrm{pH}$ with variations of 20, 50, 100, 150 and $200 \mathrm{mg} / \mathrm{L}$. The amount of rhodamin B extracted increases with increasing concentration and reaches a maximum absorption value of $1.6235 \mathrm{mg} / \mathrm{g}$ at a concentration of $100 \mathrm{ppm}$.

Keywords: Adsorbent, C-Cinnamal Calix, Rhodamin B, Synthesis, Spectrofotometer.
\end{abstract}

\section{INTRODUCTION}

In the era of globalization, the food industry is developing rapidly, food security is currently being discussed and is a very important issue to consider. Several surveys show the discovery of hazardous substances in food, even though Indonesia has food laws. People still do not get guaranteed food safety of sufficient quality because of the lack of consumers' understanding of nature, and how to determine food so that they become healthy, productive, creative and innovative individuals[1].

Food is one of the three elements of basic human needs, in addition to the needs of clothing and shelter. A food is said to be healthy if it contains one or more substances that are needed by the body. We often put the additional ingredients into food so that people are interested to eat the food that we process. Lack of attention to this often results in a deteriorating health effect, starting from food poisoning until the emergence of cancer due to the use of hazardous food additives. The addition of the additives to food is considered necessary to improve the quality of a product so that it can compete in the market. These additional ingredients include: coloring, flavoring, aroma, antioxidants, preservatives, sweeteners, and thickeners[2]. We must be careful in choosing processed foods, because not infrequently the food sold turns out to be processed using dyes that are not for food coloring. With the aim of attracting buyers or increasing the sale value, not a few producers use or add coloring that is not for food, which is certainly dangerous for our health as consumers. To protect the public from the dangers caused by these dyes, the Ministry of Health of the Republic of Indonesia has set about this dangerous dye so that people avoid adverse effects.

Rhodamin B is a synthetic dye used in the textile and paper industry. Rhodamin B is in the form of purplish red crystal powder and in solution will glow bright red. This substance is very dangerous if inhaled, swallowed, exposed to the skin and the eyes. The impact can occur in the form of irritation of the respiratory tract, irritation of the skin, irritation of the eyes, irritation of the digestive tract and the danger of liver cancer. if swallowed, it can cause irritation of the digestive tract and urine will be red or pink. Rhodamin B is carcinogenic so that the use in long-term can cause cancer. The toxicity tests of Rhodamin $B$ have been carried out on rats by subcutaneous injection and orally. Rhodamin B can cause carcinogenic when injected subcutaneously, that is sarcoma[3][4].

Metanil yellow is a synthetic coloring material in the form of brownish yellow powder, soluble in water and alcohol, slightly soluble in benzene and ether, and slightly soluble in acetone. This dye is commonly used as a textile dye, paper, ink, plastic, leather and paint. And as an indicator of acid and base in the laboratory. But in practice, in Indonesia this dye is often misused to color various types of food including crackers, noodles, tofu and yellow snacks such as fried foods.

Metanil yellow is one of the azo dyes that has been banned from being used in food. This compound is diamond so that if swallowed can cause gastrointestinal irritation. In addition, this compound can also cause nausea, vomiting, abdominal pain, fever, weakness and hypotension. In a 
study of chronic methanyl yellow exposure to white rats (Rattus norvegicus) given through their feed for 30 days, the results showed that there were changes in hispatology and ultrastructural in the stomach, intestine, liver and kidney. This shows the toxic effect of methanil yellow on rats[5].

Various methods have been carried out to deal with the problem of industrial waste, especially the removal of dyes, including coagulation, ion exchange, and ozonation methods. But these methods require relatively high costs[6]. One of the effective methods in controlling dyes is the adsorption method. Many research have been carried out on the absorption of rhodamine $b$ and Methanil yellow with various types of adsorbents, such as the activated charcoal from gumitir plant stems[7], rhizopus oryzae biomass[8], $\mathrm{MgO}$ with the help of Fe-Co-Mn nanoparticles[9]. MgO-FCN-NP rock surface activated carbon (Phoenix dactylifera) [10] and others.

The advantage of the adsorption method is the relatively low cost, although in this case, it depends on the type of adsorbent used. To get the relatively inexpensive adsorbents can be done by using waste. One of the wastes that can be used to synthesize compounds that have the potential to be adsorbents is cinnamon oil waste producing C-cinnamal calix resorsinarena (CCCR) compounds.

Calixarene is a group of cyclic macromolecular compounds composed of aromatic units. The aromatic unit is connected to another via a methylene bridge forming a cavity with an active group in it, which allows this compound to be used as a host molecule (host) for other molecules (guests), either in the form of anions, cations, or neutral compounds. Based on the reaction mechanism, the synthesis reaction of calix [4] resorcinarena is an electrophilic substitution reaction[11].

Adsorption is a physical-chemical reaction of adsorbate (pollutants) that accumulates on the adsorbent (solid surface). Adsorption is one of the most frequently methods used for removing toxic dyes in food. Some factors that can affect the adsorption capacity are:

$\mathrm{pH}$ :

The lower the $\mathrm{pH}$, the lower the adsorption capacity and vice versa, due to competition between protons and metal cations to be bound to the same functional group of adsorbent causing reduction of metal ions to be bound.

Concentration of Adsorbate:

The higher the concentration of adsorbate, the higher the adsorption capacity and vice versa.

Size of Adsorbent:

The smaller the size of the adsorbent used, the greater the adsorption capacity. When the size of the adsorbent used is the bigger, it can cause a decrease in surface area adsorbents and binding groups available.

Surface Area:

The larger surface area of the adsorbent, the more metal ions are adsorbed.

Contact Time:

The longer the contact time, the greater the adsorption capacity. This is because if there is enough contact time then more metal ions will be bound. However, contact that is too long can result in decreased metal absorption due to the accumulation of metal ions.

Temperature:

If the temperature is raised, the adsorbent molecule will move faster so it is difficult to capture and adsorb metal ions.

In this study, researchers utilize CCCR compounds resulting from the synthesis for the development of solid phase extraction methods to detect the presence of rhodamin B and methanil yellow. In this preliminary study, known how the influence of $\mathrm{pH}$ and concentrations of rhodamin $b$ and methanyl yellow on CCCR absorption.

This research is expected to provide benefits to overcome the limitations of materials and instruments, as well as methods and ligands that are good for detecting the presence of rhodamin $\mathrm{B}$ and methanil yellow dyes.The purpose of this study was to determine the optimum conditions ( $\mathrm{pH}$ and concentration) of Rhodamin B and methanil yellow using CCCR absorbent substances synthesized by using a UV-VIS spectrophotometer.

\section{MATERIALS AND METHODS}

\subsection{Material and Equipments}

The equipments used in this research are reflux set, buchner funnel, FTIR (Jasco 460 plus Spectroscopy), rotary evaporator (Heidolph Laborota 4000), Desiccator, Ultraviolet Spectroscopic Agilent $8453 \mathrm{UV}-$ Vis. For $\mathrm{pH}$ measurement, a Hitachi-Horiba Model M-5 glass electrode $\mathrm{pH}$ meter was used.

The materials are $\mathrm{NaOH}$ (merck), $\mathrm{HNO} 3$ (merck), CCCR, Rhodamin B, methanil yellow.

\subsection{Research Procedure: Taken from a combined procedure.} Effect of $\mathbf{p H}$ of rhodamine $\mathrm{B}$ and methanil yellow
solution on CCCR

Prepared $25 \mathrm{~mL}$ of $250 \mathrm{ppm}$ Rhodamin B solution with variations of $\mathrm{pH} 2,3,4,5,6$, and 7, then each solution was contacted with 0.2 grams of CCCR using a batch system, the solution then shaker at a speed of $150 \mathrm{rpm}$ for 60 minutes. Then the solution is filtered and the filtrate is collected. The filtrate was measured as the concentration values of Rhodamin B which were not absorbed by using UV-VIS spectrophotometer, and obtained the optimum $\mathrm{pH}$. The same treatment with methanyl yellow.

Effect of Concentration of Rhodamine B and Methanil Yellow Solution on CCCR

Prepared $25 \mathrm{~mL}$ of methanyl yellow and Rhodamin B solution with concentrations of 50,100, 150, 200, $250 \mathrm{mg}$ / $\mathrm{L}$ at optimum $\mathrm{pH}$, then each solution is contacted with 0.2 grams of CCCR using a batch system, the solution is shakered at a speed of $150 \mathrm{rpm}$ for 60 minutes. Then the solution is filtered and the filtrate is collected. The filtrate 
was measured by the concentration value of methanil yellow and Rhodamin B which were not absorbed by UVVIS spectrophotometer, obtained optimum concentrations of methanyl yellow and Rhodamin B. The same treatment with methanil yellow.

\section{RESULT AND DISCUSSION}

\section{Effect of rhodamine $\mathrm{B} \mathrm{pH}$ on CCCR:}

One of the parameters which determines the ability of adsorbents to absorb dyes is $\mathrm{pH}$. The $\mathrm{pH}$ affects the solubility of rhodamine $\mathrm{B}$. The effect of $\mathrm{pH}$ on the absorption capacity of rhodamin B by CCCR can be seen in and Figure 1. The $\mathrm{pH}$ variations carried out are 2, 3, 4, 5,6 and 7. In the variation of $\mathrm{pH}$ the possibility of chemical bonds between the adsorbent and adsorbate can be occur ${ }^{[12]}$. This relates to surface protonation or deprotonation of the active side of the adsorbent.

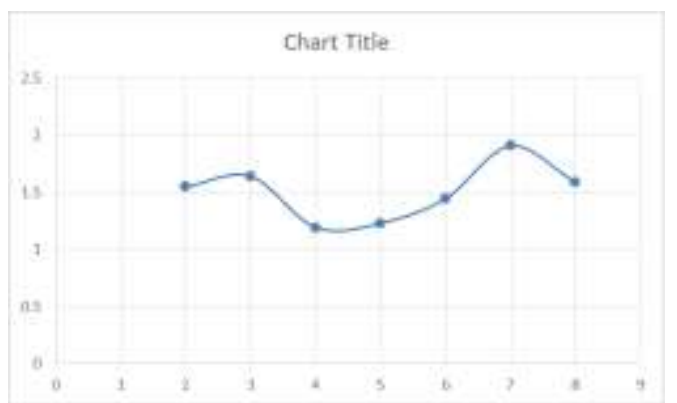

Figure 1. Graphic of the Effect of Rhodamin $\mathrm{B}$ pH on CCCR

Effect of Rhodamin B Concentration on CCCR:

The effect of rhodamine B concentration on CCCR uptake was carried out at optimum $\mathrm{pH}(\mathrm{pH} 7)$, the retention capacity of rhodamine B is shown in the Figure 2.

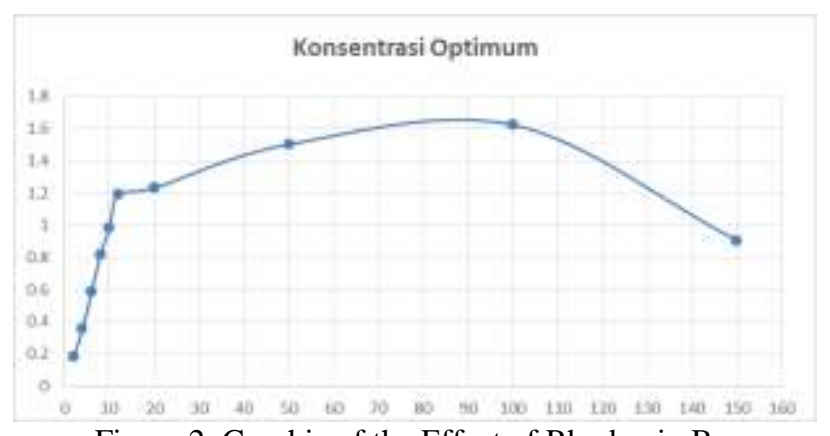

Figure 2. Graphic of the Effect of Rhodamin B Concentration on CCCR

Effect of Methanil Yellow pH on CCCR:

The influence of $\mathrm{pH}$ on the absorption capacity of methanil yellow by CCCR can be seen in Figure 3. The $\mathrm{pH}$ variations made are $2,3,4,5,6,7$ and 8 . At the $\mathrm{pH}$ variation the chemical bond between adsorbent and adsorbate can occur. This relates to surface protonation or deprotonation of the active side of the adsorbent[13].
Measurement of the effect of $\mathrm{pH}$ when adsorption of methanil yellow against CCCR is carried out at $\mathrm{pH} 3$.

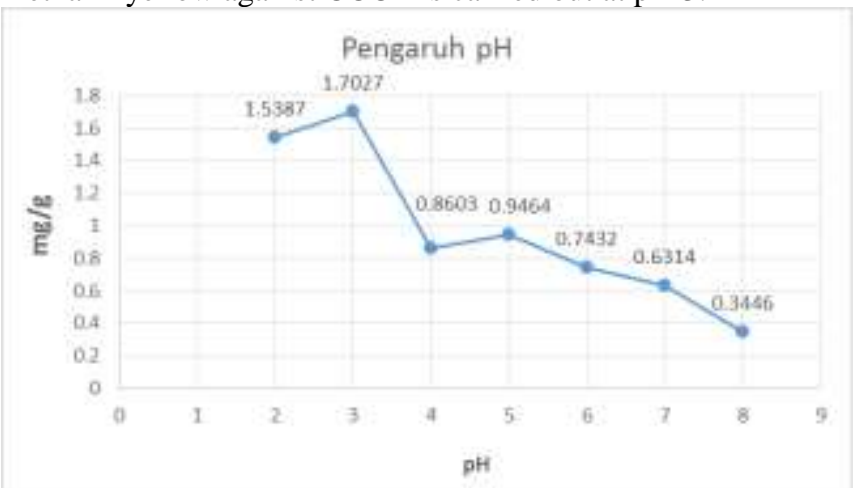

Figure 3. Graphic of the Effect of Yellow Methanil $\mathrm{pH}$ on CCCR

From Figure 1. it can be seen that CCCR can form chelate with rhodamine $\mathrm{B}$ at $\mathrm{pH}$ 7. At $\mathrm{pH}$ 4.5.6, the amount of $\mathrm{H}+$ in the solution is more causing $\mathrm{H}+$ competition with rhodamine $\mathrm{B}$ to bind to a functional group. The $\mathrm{H}+$ ion prevents rhodamine $\mathrm{B}$ from reaching the surface of the functional group, so the absorption at these $\mathrm{pH}$ is low[12]. At $\mathrm{pH} 7$ a complex formation reaction takes place between the chelate compound and the hydroxide ion. At $\mathrm{pH} \mathrm{8}$, there is a reduction in the number of $\mathrm{H}+$ ions, while $\mathrm{OH}-$ in the solution increases, so it is thought that competition occurs between $\mathrm{OH}-$ and functional groups in binding to form deposits. With the formation of sediment, less rhodamine $\mathrm{B}$ is retained by CCCR resin[13].

Figure 2. shows the effect of rhodamine $\mathrm{B}$ concentration on CCCR. The amount of rhodamine B extracted increases with increasing metal concentration, and reaches a maximum absorption value of $1.6235 \mathrm{mg} / \mathrm{g}$ at a concentration of $100 \mathrm{ppm}$. According to John (1988), an increase in solution concentration will increase the absorption of metal ions until there is a constant absorption at an increase in concentration, this happens because on the CCCR surface is no more empty space that can be filled by positively charged ions, meaning that the number of positive rhodamin B is no proportional anymore to the active groups on the surface. it can also be said on the surface has occurred saturation.

From Figure 3.6 it can be seen that CCCR can form chelate with methanyl yellow at $\mathrm{pH} 3$. At $\mathrm{pH} 2$ the amount of $\mathrm{H}+$ in a lot of solution so that $\mathrm{H}+$ competition with metanil yellow is suspected to bind to a functional group. The $\mathrm{H}+$ ion prevents metanil yellow from reaching the surface of the functional group, so the absorption at this $\mathrm{pH}$ is low. At $\mathrm{pH} 3$ a complex formation reaction takes place between the chelate compound and the hydroxide ion. At $\mathrm{pH} \mathrm{4,} \mathrm{there} \mathrm{is} \mathrm{a} \mathrm{reduction} \mathrm{in} \mathrm{the} \mathrm{number} \mathrm{of} \mathrm{H}+$ ions, while $\mathrm{OH}$ - in the solution increases, so it is thought that competition occurs between $\mathrm{OH}$ - and the functional groups in bonding to form deposits. With the formation of precipitate, less methanil yellow is retained by CCCR resins

[13] 


\section{CONCLUSION}

Based on the results of this study, it has been done regarding the optimum conditions of rhodamin $\mathrm{B}$ and methanyl yellow, it can be concluded that: The optimum $\mathrm{pH}$ of rhodamine $\mathrm{B}$ against CCCR occurs at $\mathrm{pH} 7$, and the concentration at $100 \mathrm{ppm}$. The optimum $\mathrm{pH}$ condition of methanil yellow against CCCR occurs at $\mathrm{pH} 3$.

\section{REFERENCES}

1. Indrati, R. Gardjito, M, 2014. Pendidikan Konsumsi Pangan, Bumi Aksara, Jakarta.

2. Winarno, F.G. 1992. Kimia Pangan dan Gizi, Jakarta. PT. Gramedia.

3. Mayori, R, Marusin, N and Tjong, D,H, 2013. Pengaruh Pemberian Rhodamin B Terhadap Struktur Histologis Ginjal Mencit Putih ( Musmuscunis L). Jurnal Biologi Universitas Andalas . J.Bio.UA) 2 (1);(ISSN: 2303-2162); 4349.

4. Herman. (2010). Identifikasi pewarna rhodamin b pada minuman ringan tanpa merek yang dijual di pasar sentral kota Makassar. Jurnal Media Analisis Kesehatan, 1(1), 33-36.

5. Sarkar, R. and A.R. Ghosh. 2013. Metanil yellow - An azo dye induced hispathololgical and ultrastructural changes in albino rat (Rattus norvegicus). The Bioscan 7(1):427-432, 2012 [www.thebioscan.in] (diunduh bulan April 2013).

6. Munawaroh, I. 2012. Pemanfaatan Bonggol Jagung Sebagai Adsorben Rhodamin B dan Metanil Yellow. Skripsi. Yogyakarta UIN Sunan Kali Jaga Yogyakarta.

7. Sahara. E.Gayatri, P.S.\& Suarya, P. 2018. Adsorpsi Zat Warna Rhodamin b Dalam Larutan Oleh Arang Aktif Batang Tanaman Gumitir Teraktivasi Asam Fosfat. Indonesian E. Journal of Applied Chemistry, 6(1), 37-45.

8. Das, S.K,. Bhowal. J,. Das, A. R,.\& Guha, A. K. 2009. Adsorption behavior of Rhodamin B on Rhizopus oryzae biomass, Langmuir, 22(17), 7265-7272. https://doi.org/10.1021/la0526378.

9. Rahdar. S. et al. 2019. Synthesis and Characterization of $\mathrm{MgO}$ Supported Fe-Co-Mn Nanoparticles with Exceptionally High Adsorption Capacity for Rhodamin b dye.Journal Of Materials Research and Technology, (x x). 1-11. https://doi.org/10.1016/j.jmrt.2019.06.041.
10. Danish, M,. Khanday, W. A., et al. 2017. Application of Optimized Large Surface Area Date Stone Activated Carbon for Rhodamin b Removal from Aqueus Solution: Box-Behnken Design Approach. Ecotoxicology and Environmental Safety. 139 (Desember 2016). 280290. https://doi.org/10.1016/j.ecoenv.2017.02.001.

11. Etika, S.B. Nasra.E. Rilastika,I. 2018. Synthesis and Characterization of C-Cinnamal Calix[4 Resorcinarena from Cinnamon Oil West Sumatra. ICOMSET. IOP Conf. Series Material Science and Engineering 335 (2018) 012028.doi:10 1088/1757-809X/335/LOI 2028.

12. Refilda., Zein Rahmiana.Rahmayeni, 2001,Pemanfaatan Ampas Tebu Sebagai Bahan Alternatif Pengganti Penyerap Sintetik Logamlogam Berat Pada Air Limbah,Skripsi., Padang: Universitas Andalas.

13. Is Fatimah. 2000. Penggunaan Na-Zeolit alam Teraktivasi sebagai Penukaran Ion $\mathrm{Cr} 3+$ dalam larutan larutan . LOGIKA. Vol. 4 No 5. 